\title{
Una minga por la vida en medio de la pandemia
}

\section{Minga in defense of life in the middle of a pandemic}

\author{
Pablo-Andrés Martínez-Silva ${ }^{1}$
}

\begin{abstract}
Forma de citar: Martínez Silva PA. Una minga por la vida en medio de la pandemia. Salud UIS. 2020; 52(4): $366-367$.
\end{abstract} doi: https://doi.org/10.18273/revsal.v52n4-2020002 (c) (i)

Minga significa pensar/palabrear/hacer en común por la comunalidad. Por lo anterior, una minga integra conocimiento, diálogo y acción. Esto no es ajeno a la Minga Suroccidente, convocada por el Consejo Regional Indígena del Cauca, el Consejo Regional Indígena del Huila y el Consejo Regional Indígena de Caldas, organizaciones que agrupan a la casi totalidad de autoridades tradicionales de estos departamentos.

En este caso la invitación es desarrollar esta actividad en pro de la Vida, el Territorio, la Democracia y la Paz. La Vida, porque se han venido cegando vidas, no solo de líderes, sino de ciudadanos del común, y toda vida es valiosa; el Territorio, porque distintos proyectos del llamado Desarrollo, desconoce otras formas de construir una territorialidad no antropocéntrica, colocando el riesgo no solo la pervivencia de la biodiversidad, sino de la memoria biocultural construida por siglos; la Democracia, porque se ha entronizado una práctica de gubernamentalidad que desconoce al Otro, a sus modos de vida, lo que se observa en el desconocimiento de la comunalidad establecida como pacto social en la Constitución Política de 1991; y la Paz, porque esta es un resultado de que este pacto se cumpla.

La Minga tuvo una antesala. A comienzos de la pandemia Covid-19, las organizaciones convocantes llamaron al gobierno nacional para establecer una respuesta de pervivencia y contingencia articulada. Luego de varias reuniones virtuales, cada una de estas presentó su Plan, el cual integraba distintos sectores, ya que se reconocía tempranamente la necesidad de una acción sistémica/holística que además fuese intercultural, es decir, producto de un diálogo de saberes entendido como diálogo entre actores políticos. Con acuerdos establecidos, su concreción se dilató, y correspondió a las organizaciones responder por su cuenta, teniendo presente sus límites.

Paralelo a este proceso, vino el deterioro del ambiente social, económico y político propio de la pandemia, por todos conocido. En este, la ruralidad y las poblaciones con alta vulnerabilidad, en la cual se incluye a los indígenas, ha llevado la peor parte. Esto sumado a la promesa incumplida de accesibilidad del Sistema General de Seguridad Social en Salud en área geográficas de baja densidad poblacional, una de las razones por las cuales hoy es objeto de disputa política ante su interés de reforma.

Si bien, estas organizaciones pusieron en marcha dispositivos para la contención de la pandemia, que incluyó, control territorial por parte de su Guardia Indígena o Cuidanderos del Territorio, puntos de desinfección y vigilancia de la entrada y salida de su población, uso de tapabocas, distanciamiento físico expresado en limitación de actividades colectivas, difusión de mensajes clave en español y lenguas propias, rastreo comunitario, entre otras, a lo cual se le articulaba todo el trabajo desarrollada por sus agentes de cuidado tradicional - sabedores - en el marco del Sistema Indígena de Salud Propio e Intercultural de sus territorios, las presiones llegaron a un punto insoportable. De ahí la necesidad de visibilizarse, movilizarse, plantearle una alternativa el país. Este último venía de una tensión ya expresada en protestas anteriores, razón por la cual la propuesta ha sido acogida por muchos sectores, en espera de que sea el impulso para hacer el debate necesario.

1. Universidad Nacional de Colombia. Bogotá, Colombia.

Correspondencia: Pablo Andrés Martínez Silva. Dirección: Carrera 2281 - 80 oficina 201 Bogotá D.C. Correo electrónico: pmartinez@sinergiasong.org 
Es así como se decide hacer una movilización desde Cauca, Huila y Caldas hacía Bogotá. No es una decisión ligera. Antes de ella, sus sabedores se sentaron alrededor de las tulpas o sus lugares sagrados a "catear", una forma de análisis de riesgo propio de diferentes pueblos. De ahí, surgieron orientaciones que fueron articulándose con otras orientaciones, que incluyeron el uso del tapabocas, la dotación de desinfectantes de manos tanto químicos como naturales, el consumo de plantas medicinales, la implementación de vaporizaciones, y otras tantas más que igualmente se han empleado en sus territorios.

Muchos se concentrarán en la "evidencia" que soportan estas acciones y extenderán una sonrisa, propio del discurso del racismo y la xenofobia. De mi parte veo una conciencia profunda de autocuidado, esto sí evidente, desde unos referentes propios e híbridos, que lejos de comprenderlos como sociedad, son objeto de burla ante el abandono a la promesa de contar con una nación multiétnica y pluricultural en la que quepamos todos.

La Minga es política porque invita al diálogo entre distintas cosmovisiones. Es imposible que no lo sea, como sugieren algunos, porque lo que se juega en ella es la Casa Grande, la Pacha Mama, la Madre Tierra, de lo cual esta pandemia es el reflejo de la situación, como lo es la crisis ecológica y el cambio climático. No se puede responder a este virus sin responder a todo. Esa es la invitación.

¡Guardia, Guardia! ¡Fuerza, Fuerza! 